The Open Civil Engineering Journal
CrossMark
Content list available at: www.benthamopen.com/TOCIEJ/
DOI: $10.2174 / 1874149501610010179$

RESEARCH ARTICLE

\title{
A Three-Dimensional Project Portfolio Management Framework for Construction Companies
}

\author{
Yunna $\mathrm{Wu}$, Haobo Zhang and $\mathrm{Hu} \mathrm{Xu}^{*}$ \\ North China Electric Power University, Beijing, China
}

Received: January 26, 2016

Revised: February 26, 2016

Accepted: March 04, 2016

\begin{abstract}
Many construction companies struggle with multi-project optimization and change despite adhering to normative project portfolio management instructions and best practices. One explanation is that managers lack extensive multi-project management experience from which to apply related theory to practical outcomes. This paper proposes a three-dimensional segmentation framework to guide companies with no prior project portfolio management experience in establishing a project portfolio management system and applying it to their situation. The framework decomposes an expansive and disorganized multi-projects group into a set of simple activities from three different dimensions (project type, project phase, and the management layer) to facilitate the introduction of project portfolio management theory and principles. Then, a case study illustrates the application and utility of the proposed framework. Although this framework was initially developed for a Chinese electric power construction company, it can also be applied to other construction companies in similar circumstances worldwide.
\end{abstract}

Keywords: Construction project management, Management practice, Project portfolio management, Three- dimensional framework.

\section{INTRODUCTION}

Construction companies, even small and medium-sized firms, are often engaged in many types of construction projects constituting a complex multi-project group [1]. Traditional management modes are project-centric. That is, a project is led by a project management team from start to finish, and projects are relatively independent [2]. Although many companies classify their projects into different groups by certain rules, and categorize projects into portfolios, these projects are still managed independently and lack the exchange of resources, personnel, technology, and knowledge among them. This prevents companies from fully benefiting from project portfolio management (PPM). When the size of a company is still small, the problem can be alleviated by interaction among project managers and coordination of the company's senior leaders. As a company grows, the number of operational projects increases rapidly. Excessive coordination overburdens leaders and prevents sufficient focus on their own work. In addition, the neglect of project synergies causes greater losses. With increasing market competition, construction companies require new approaches to the integration, optimization, and management of projects.

PPM is an emerging business management strategy that focuses on project selection, prioritization, integration, management, and control in the multi-project context that is prevalent in modern organizations [3]. PPM applies suitable methods to project selection, project evaluation, portfolio optimization, portfolio balance, resources allocation, and stakeholder communication to achieve strategic benefits [4].

PPM has been established as a core method for project management research, product development research, and company management practices during the past decade [5]. Substantial research has addressed the tools and techniques for project selection [6 - 8], portfolio evaluation [9 - 11] prioritization [12], and resource management [13 - 15]. The related research is abundant. Global PPM standards [16, 17] and practical toolkits have been developed [18, 19].

\footnotetext{
* Address correspondence to this author at the North China Electric Power University, No.2, Bei Nong Road, Hui Longguan Town, Chang Ping District, Beijing, China; Tel: +86 15810305848; E-mail: 642345671@qq.com
} 
These standards and toolkits have facilitated PPM adoption for many firms.

In recent years, practitioners and researchers have been eager to identify the factors that affect project portfolio achievement and to determine how to increase the likelihood of success. Heising [20] argues that innovation can facilitate and sustainably improve portfolio success in product development in the long term. The influence of internal stakeholders, senior managers [21 - 23], middle managers [24, 25] and project managers [26] is also demonstrated as a key success factor for project portfolios [27, 28]. Various studies support the notion that the formalization of singleproject management [29 - 31] and PPM [32] is associated with project portfolio success. However, excessive formalization may constrain creativity and interrupt innovation activities [33, 34]. Moreover, Jonas, et al. [35] conceptualize management quality as a multi-dimensional construct consisting of information quality, allocation quality, and cooperation quality, which allows the anticipation of project portfolio success earlier than the point at which established success criteria become measurable. Killen and Hunt [36] propose a capability maturity model to assist in the development of robust PPM capabilities that will continue to evolve and stay relevant in dynamic environments. Petro and Gardiner [37] link the steering committee (Senior managers) and project manager's influence to the effectiveness of portfolio management and the business efficiency. Moreover, in [38] and [26] steering committee's importance in PPM were studied and concluded as important in applying governance.

However, few construction companies have successfully established and professionalized PPM systems. Many companies struggle with the management of multiple interdependent project portfolios. Conflicts associated with multiple projects can overwhelm employees [39]. Martinsuo [5] believes a possible explanation is a lack of awareness concerning practice and context. Some studies view PPM as a rational decision process; however, the day-to-day practice of PPM may be less rational and certain than originally assumed $[40,41]$. Some researchers argue that a number of different PPM frameworks, process variants, and derivatives exist; however, these methods can be excessively and disparately used when companies embrace PPM principles [42]. For a company with no established PPM system, it is difficult to compose the required methods into comprehensive PPM application. In addition, the research on PPM for the construction industry is still scarce. Many studies focus on project selection, prioritization, and optimization within the portfolio [43 - 45]; specifically, "how to do the right work." In addition to effective project selection, the output of construction projects is influenced by the level of project governance. More construction companies experience the problem of "how to do the work right," and these companies require special guidance.

A PPM framework is an instrument or guidebook that assists enterprises in building a mature PPM system to improve their management and competitiveness and to avoid elimination from the market. A quality framework should meet the following requirements: (1) Applicable to as many companies in one or more industries as possible. (2) The ability to be modified according to different enterprises' special characteristics. (3) Most importantly, the framework should be easy to operate, particularly for new companies without rich experience.

This paper proposes a PPM framework to assist construction companies in problem solving. The remainder of this paper is organized as follows: Section 2 provides a literature review of current PPM knowledge to find the problems faced by construction managers. Section 3 provides a PPM framework, its core ideas, and discusses three-dimensional segmentation. The three different roles in the framework are defined in Section 4. A case study illustrates the application of the PPM framework in Section 5, and the results are presented in Section 6. Conclusions and suggestions for further research are presented in Section 7.

\section{LITERATURE REVIEW}

PPM research has been ongoing for many years [46]. However, these studies have rarely been applied in the construction industry. This is not because there are no multi-project management problems in the industry. On the contrary, many construction companies are engaged in multiple projects of various types and sizes. PPM is suitable for such companies to improve management efficiency. However, some reasons impede the construction companies to embrace PPM.

\subsection{Preference for Selection Over Governance}

Currently, most of the research in the PPM field has focused on the problems of project selection, project evaluation, portfolio optimization, and portfolio balance $[6,8,47]$, whereas the research on portfolio operations, organizational governance, and resource allocation is relatively scarce [48]. One possible reason for this phenomenon is that PPM originated from financial sector portfolio management, the science of decision making on investment mix and policy, matching investments to objectives, asset allocation for individuals and institutions, and balancing risk against 
performance [19]. In the financial sector, the benefits of financial products depend on the selection and balance of the portfolio. Moreover, many studies on PPM are used for R\&D, IT, and the production field [49 - 51], in which the performance of project portfolio mainly depends on the selection, optimization, and balance of portfolio components. Thus, other issues are ignored. For the construction sector, selecting appropriate components is just one factor for portfolio success. The output of a portfolio also depends on its implementation [52]. Ignoring project portfolio implementation can equate to a lot of the opportunity to improve the value of projects.

\subsection{A Lack of Systematic Research}

There are many subtopics associated with PPM. To study these issues thoroughly, researchers usually focus on one or two and propose specific methods and solutions. However, this is not conducive to systematic problem solving [3]. The application of these methods and solutions requires the appropriate conditions. Sometimes these conditions are contradictory, which complicates their integration to form a complete PPM solution. Without a basic PPM framework, a single method is accepted and applied with difficulty [5]. Companies require a complete solution to help them solve various problems in PPM.

\subsection{A Lack of a Special Guidebook}

Some PPM guidebooks have already been designed to help companies build their PPM systems $[16,17]$. These guidebooks provide general guidance for companies mired in multi-project management problems. Seeking to be useful to many types of companies in different sectors, these guidebooks generalize to solve common problems encountered by different companies. These guidebooks can be used in various industries, but they may not be the best solutions for each industry because they lack the ability to solve the specific problems in each industry [53]. Construction projects have many characteristics: (1) Irreversibility-once a construction project starts, it is difficult to terminate [54]. Otherwise, the construction project will suffer heavier losses. (2) Construction projects can be divided into relatively independent stages. (3) The involvement of many stakeholders including owners, suppliers, contractors, consultants, and even government [55]. (4) Technical complexity-most construction projects involve complicated construction technology. (5) Project output is largely determined by the level of project governance. General PPM guidebooks lack appropriate solutions for problems associated with these specific characteristics, and the construction industry needs specialized PPM guidelines.

\section{THE PROJECT PORTFOLIO MANAGEMENT FRAMEWORK FOR THE CONSTRUCTION INDUSTRY}

The projects owned and executed by construction companies are composed of an extensive multi-projects group. These projects are significantly different in terms of schedule, technology, resources, and management. In traditional construction project management, each project is managed by a project management team. Sometimes these projects are simply classified by certain rules. Projects in the same type are under the supervision of senior managers or middle managers. The simple classification often implies that they are disparate and hard to unify under management. More often, middle managers just perform a supervisory and coordinating role. The core of management is the project manager. Projects are managed separately with a lack of cooperation (Fig. 1).

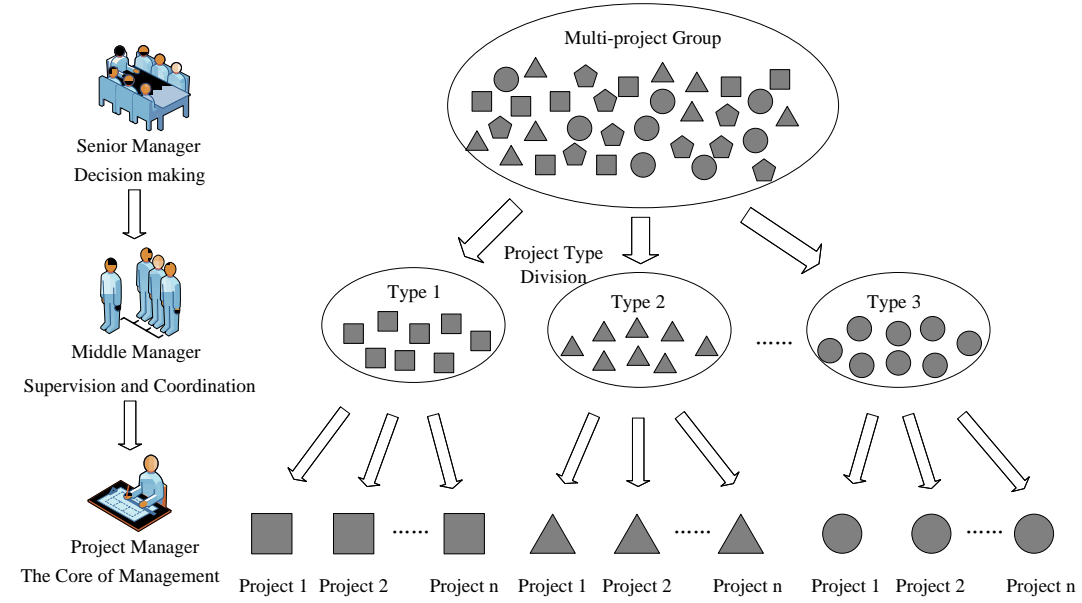

Fig. (1). The procedure of traditional construction project management. 
The application of PPM theory and methods requires categorization of the multi-projects group by certain rules and transferring the management core from project to portfolio. We propose a three-dimensional segmentation framework to decompose and reengineer the vast and disorganized multi-projects group into simple and clear activities (Fig. 2).

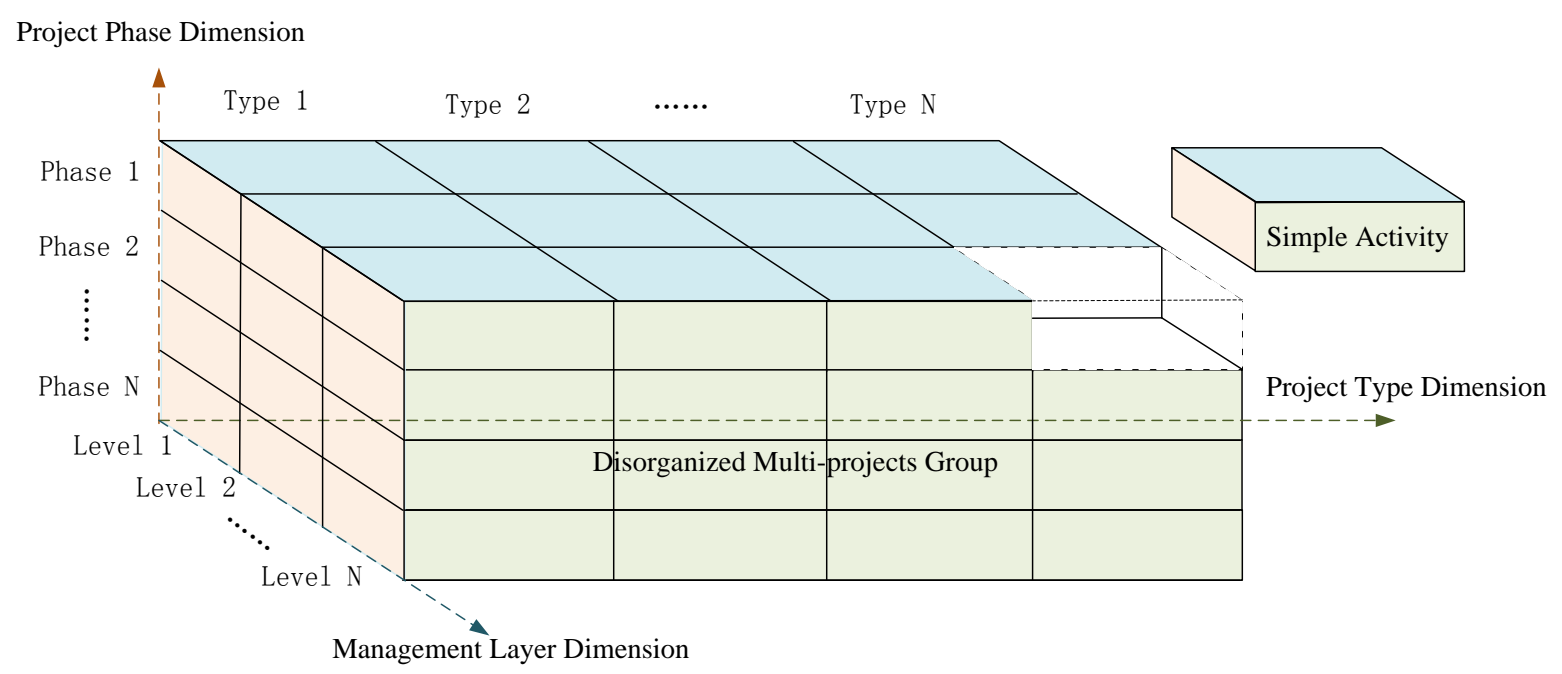

Fig. (2). The three-dimensional segmentation framework of PPM.

\subsection{The First Dimension: Project Type}

There are many types of construction projects. They are generally classified as residential, commercial, industrial, infrastructural by their type [56]. Each type can be further subdivided. A large construction enterprise often engages in many types of construction projects, which are quite different with respect to technology, knowledge, resources, and management methods. Therefore, we propose preliminary segmentation for themulti-projects group according to the project type. After segmentation, similar projects can be classified into the same portfolio. This decreases the complexity of project comparison and selectionand facilitates the introduction of PPM. The project division is flexible. Even the same type of project, if disparate and representative, can be subdivided into different categories.

\subsection{The Second Dimension: Project Phase}

A project can be divided into many different phases according to the specific work content. For example, the Project Management Institute [17] separates projects into concept development, feasibility study, design, prototype, and the build and test phase. The methods and managerial key points are different in the various phases. Such division is useful for construction projects. A construction project generally consists of several relatively independent phases or branches with different technology, knowledge, and resource requirements. Project payments are often paid on completion of each phase. These phases can be considered subprojects. Some small companies even specialize in one phase of construction. The differences among phases lead to complexities in project comparison and collaboration, even if the projects belong to the same type. However, some different types of construction projects have similarities at some phases. For example, the foundation work of many different types of projects uses the same standards and technologies, and the construction of substation facilities in many power projects is practically identical and could be managed by the same standards. Therefore, it is necessary and feasible to divide a construction project into several phases. The second dimension we propose is to divide projects into different programs according to the project phase. Significantly, the relationships of the phases are not only sequential but are juxtaposed or overlapping.

\subsection{The Third Dimension: Management Layer}

The described segmentation divides the complex multi-projects group into many similar programs. Although there are still a substantial number of works in each program, these works are significantly distinct. Basic-trained employees can complete some programs, others are suited to specialized personnel, and certain work requires experienced managers. We identified all of the program works and divided these works into three categories: decision making, schedule, and execution. Finally, the works are assigned to different managers (senior managers, middle managers, and project managers) to complete the segmentation of the third dimension. 
The three-dimensional segmentation is a process of both decomposition and reengineering. Complex work is broken down into simple tasks. Similar tasks are reassembled together and assigned to different personnel. With the segmentation of type and phase dimensions, similar projects are grouped to form project programs and portfolios. The segmentation of the management layer classifies and assigns work to the appropriate personnel (Fig. 3). Barriers between projects are removed. The management core is elevated to the portfolio level. This helps the introduction of PPM theory and methods, as detailed in Table 1. After the first dimension segmentation, similar projects are classified into similar types and compared. This process facilitates project identification, categorization, prioritization, assessment, and selection. The second dimension segmentation groups similar project components to form various programs. This process allows the introduction of portfolio performance management knowledge, portfolio resource management, portfolio communication, change management, and portfolio risk management. The third dimension segmentation provides a more appropriate context for portfolio resource, communication, change, and risk management.

Table 1. Three dimensions and their contributions to the introduction of PPM theory and methods.

\begin{tabular}{|c|c|c|c|}
\hline PPM Knowledge & Project Type & Project Phase & Management Layer \\
\hline Project identification and categorization & o & & \\
\hline Project assessment, selection and prioritization & o & & \\
\hline Portfolio balancing & o & o & \\
\hline Portfolio performance management & & o & o \\
\hline Portfolio resource management & & o & 0 \\
\hline Portfolio communication and change management & & o & o \\
\hline Portfolio risk management & & $\circ$ & $\circ$ \\
\hline
\end{tabular}

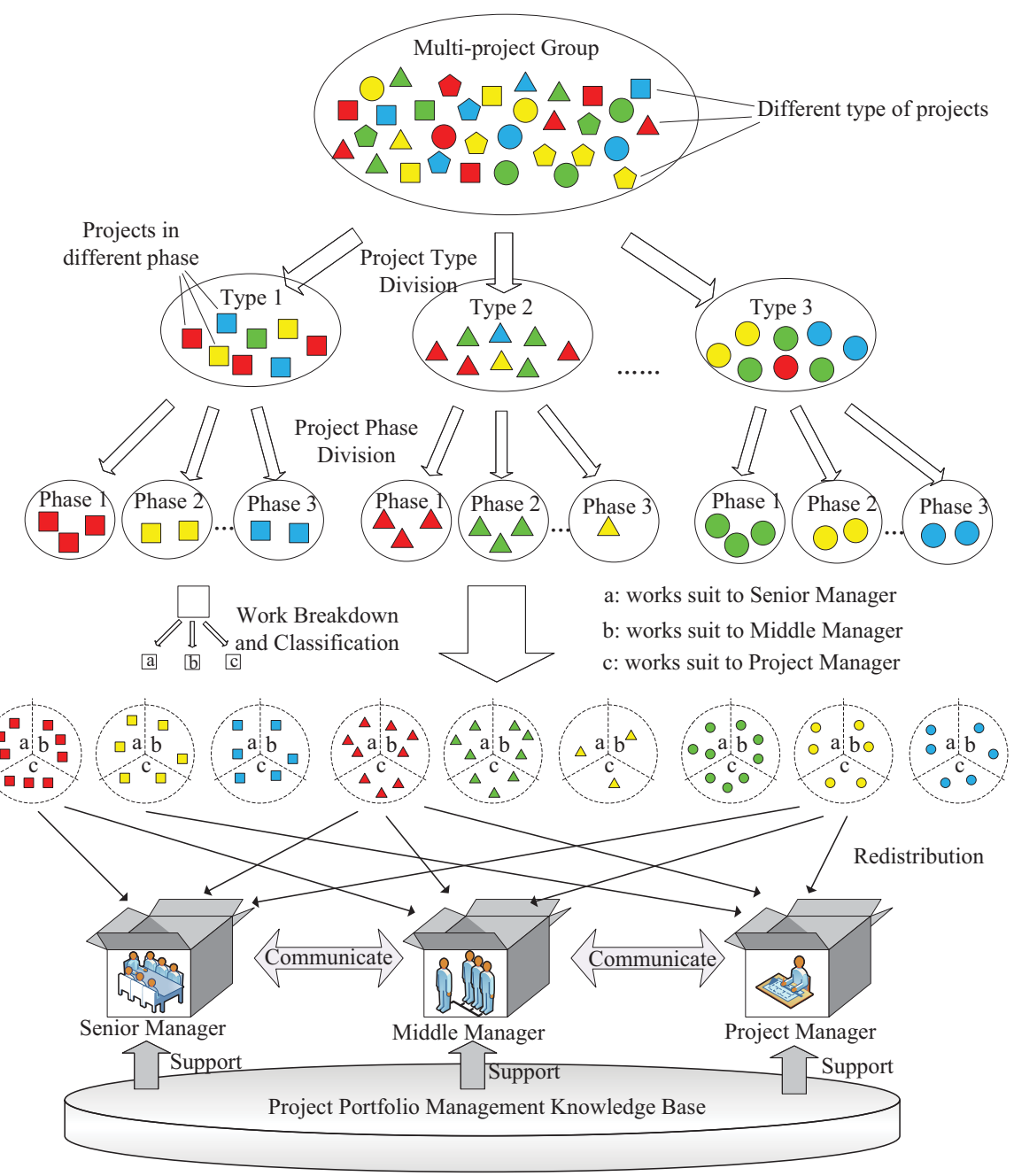

Fig. (3). The procedure of three-dimensional segmentation. 
The three-dimensional segmentation framework segments a complex multi-projects group into several simple activities and reassembles them to form project programs and portfolios. The next section defines the roles in each management layer.

\section{ROLE DEFINITION}

Multiple actors involved in the temporary and permanent aspects of operations share interests and participate in project portfolio execution. Therefore, these actors perform managerial tasks and assume a level of PPM [57]. Many recent studies use three main categories: senior manager, middle manager or portfolio manager and project manager. Traditional construction PPM is project-centric. Project managers are responsible for the main functions of management including planning, execution, and control. Middle managers are usually responsible for the supervision, coordination, and communication, and senior managers are responsible for decision making. Because different projects are often undertaken by different project managers, there is a lack of interaction and communication among projects. In addition, the oversimplification of project classification causes disparate projects in the same portfolio. The coordination of middle managers has limited effects. PPM theory and methods can be applied effectively.

Three-dimensional segmentation groups similar projects to form project programs, and the barriers between projects are removed. This provides an opportunity for full PPM.We define the roles in each management layer to elevate the core of management to the portfolio level and to improve the performance of PPM.

\subsection{Senior Manager}

The main responsibility of senior managers is decision making. Although duties vary according to each company, the responsibilities of senior managers include developing company strategy, selecting and aborting projects in the portfolio, and arranging the portfolio project priority. Senior management positions are usually held by the organization's chief executives. Many researchers have proposed various methods for project selection and prioritization and to assist senior managers in fulfilling their duties. Such methods include the analytic hierarchy process (AHP) [58, 59], the analytic network process (ANP) [60, 61], fuzzy [62, 63], and multi-objective decisions (MOD) [64, 65]. Managers select the appropriate supporting method according to the specific situation.

\subsection{Middle Manager}

In traditional construction PPM, projects are managed respectively. The project governance work is in the charge of project managers. Middle managers can exert limited influence on project governance. With three-dimensional segmentation, middle managers become the core of PPM. It is the middle manager's duty to govern the project portfolio according to senior management decisions. The responsibilities of middle managers include developing project portfolio execution plans, allocating resources among projects, supervising project implementation, collecting and analyzing project data, communicating with stakeholders, and providing support information for senior decision makers. According to the project components that they manage, middle managers are categorized into two groups: portfolio manager and program manager. The portfolio manager is in charge of a portfolio composed of projects from the same type, whereas the program manager is in charge of programs composed of projects in the same phase. The portfolio manager places emphasis on planning and analyzing, and the program manager is concerned with program governance. Both roles require extensive experience, skills, and knowledge. Abundant research addresses the role of the middle manager $[11,24,53,66]$.

\subsection{Project Manager}

Some studies argue that successful PPM requires project managers to master construction technology, possess project management knowledge, and to have superior communication skills [67]. The lack of skilled project managers complicates PPM and lowers the likelihood that the potential benefits will be obtained. The new PPM framework allows middle managers to assume a portion of the project manager's responsibilities. Project managers are no longer the core of PPM. Project managers are responsible for single-project daily operations such as project implementation, recording, and reporting. The reduction of work, including planning and communication, frees them to specialize in construction technology. 


\section{CASE STUDY}

The section will present a real-world case study of how the proposed framework was applied to clarify its purpose and function.

\subsection{The Yineng Company}

Lanzhou Yineng Power Limited (hereinafter referred to as Yineng) is a large electric power construction company in Gansu, China. Initially, the company was mainly engaged in thermal power plant, substation, and transmission line construction projects. Recent changes in China's energy policy have reduced the number of thermal power plant projects, whereas the new energy electricity markets have experienced unprecedented prosperity. Yineng seized the opportunity to develop new energy business. Because of abundant wind and solar resources and a favorable market environment in Gansu [68], Yineng has undergone a period of rapid development. The major businesses of Yineng now include wind and solar power stations, substations, and transmission lines. Although the number and scale of projects experienced explosive growth, managerial competency did not keep pace with company development. This limited the development of the company and its ability to compete in a fierce market. The CEO of Yineng hoped to improve the company's management with the application of PPM.

\subsection{The Three-Dimensional Segmentation of Yineng}

\section{Step 1: The Segmentation of Project Type by Dimension}

The quantity and types of Yineng-managed projects are numerous. With the exception of electrical projects, Yineng is even engaged in real estate and infrastructure projects. During the period of rapid development, the company exploited all possible lucrative opportunities. However, Yineng recognizes that it must now exercise caution with project selection. The company's CEO admitted that choosing new projects was a significant problem because, with the exception of profit, the selection index to compare projects was unclear. According to the principle of project-type segmentation, we divided all the projects the company owned into the five categories of wind power station, solar power station, substation, transmission line, and other construction projects. Projects in the same type are compared directly. For different project types, the weights are determined by company strategy. However, the other project type is unique. Projects in this type remain disparate and incomparable, and further segmentation is unsuitable. Because only a few projects are of this type, they were treated as special programs, and single-project management was retained for these projects.

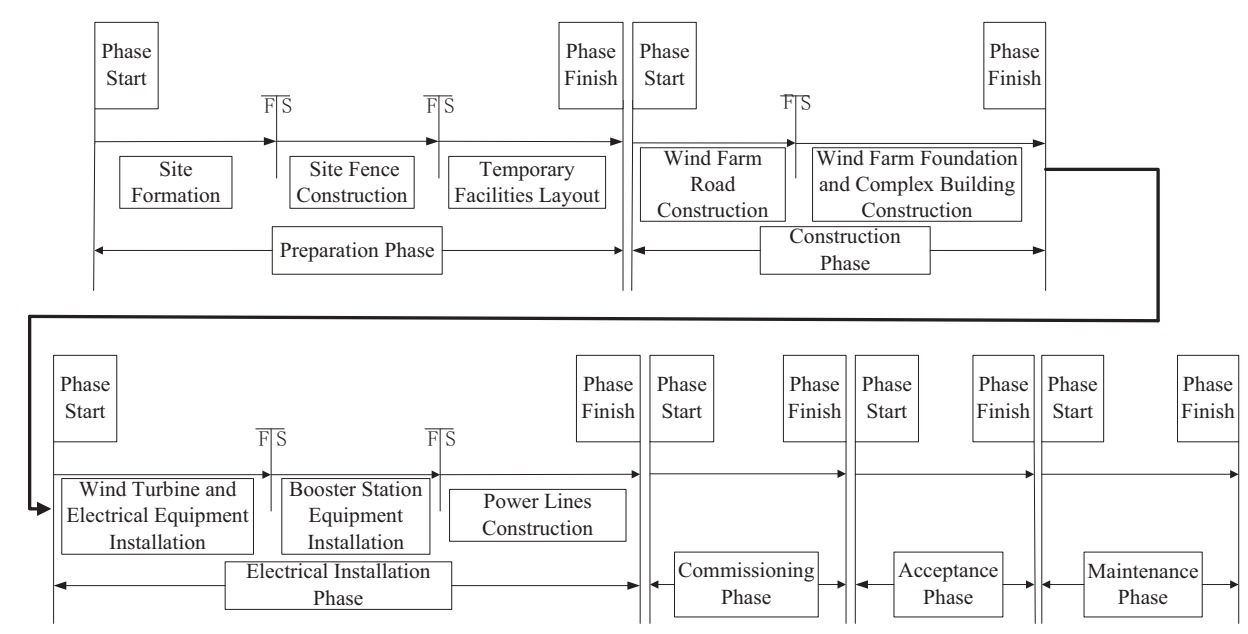

Fig. (4). The phase division of wind farm construction projects.

\section{Step 2: The Segmentation of the Project Phase Dimension}

According to the principle of the project phase dimension, we divided the projects into independent and significantly disparate phases for unified management. To achieve standardized management, we adopted the National Power Construction Standards as the main basis when referring to Yineng's management routine. A substantial number of experienced engineers and experts were involved in this process to ensure the maximum likelihood of true and accurate information. An exposure draft was delivered to company management to elicit practical input and feedback. 
The segmentation scheme was finalized after several amendments. Taking the wind farm construction project as an example, the whole project is divided into the preparation phase, the construction phase, the electrical installation phase, the commissioning phase, the acceptance phase, and the maintenance phase in level I. Electrical installation is further divided into wind turbine and electrical equipment installation, booster station equipment installation, and power lines construction in level II (Fig. 4).

\section{Step 3: The Segmentation of the Management Layer Dimension}

The management layer segmentation is responsible for the decomposition and identification of the work content in each phase and role designation with respect to the works. This is a complex but significant process that must ensure that no work is omitted, every work is designated to the appropriate role, and every role knows how to complete the tasks. We referred to the National Electric Power Company's construction industry standards and the existing workflows of the company and invited the company's management staff to participate in discussions. With the help of a WBS (Work Breakdown Structure), we identified all the work throughout the projects. By simulating the entire work process on a sand table, we could check the integrity of the task entirety and ensure no tasks were overlooked.

To adapt to the new segmentation framework, we first fine-tuned the company's organizational structure. We selected some project managers with extensive management experience and knowledge as middle managers to increase the number and capability of middle managers. The original work assignments were adjusted to accommodate the change in organizational structure; therefore, the new assignments were conducive to the success of the project portfolio. The recommendations of The Standard for Portfolio Management [16] and the actual situation of the company were both considered during this process. The exposure draft was released to the company managers to determine the usability of the assignment program and to ensure that the program reflected the needs of the various managers. Based on manager feedback, we continually revisited and perfected the program. Finally, we recommended appropriate methods for each type of manager to assist in the implementation of their work.

\subsection{Implementation of PPM}

Although we decomposed Yineng's multi-projects group successfully, and a large number of PPM methods were proposed to solve the problems faced by managers, complexity remains with respect to the knowledge integration into company operations. This process includes change in inherent habits and the acceptance and application of new knowledge. For a company without mature experience, for example, Yineng, this process is difficult. This may explain the poor performance of PPM guidance in practice. To solve this problem, we integrated the three-dimensional segmentation framework and PPM methods into an information system to establish the PPM information system. The core ideas of the system are effective integration of knowledge, rapid collection and transmission of information, and standardization of processes (Fig. 5).

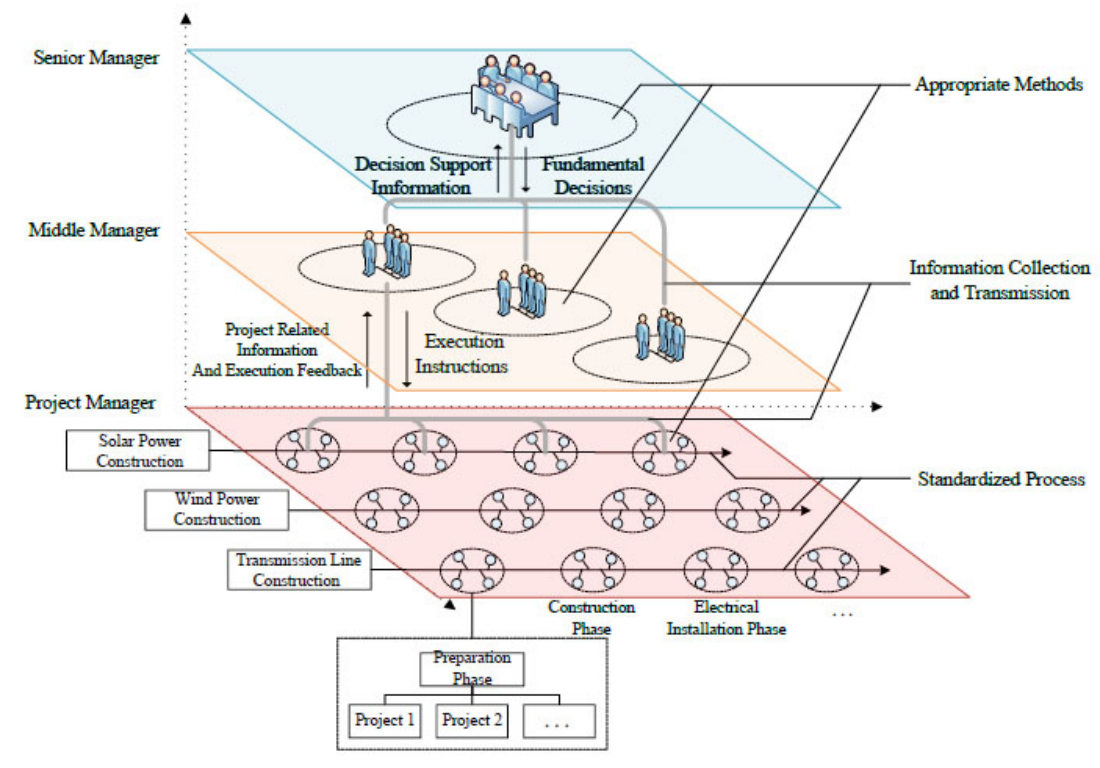

Fig. (5). The PPM information system of Yineng. 
Consistent with Yineng's situation, the appropriate methods were selected and integrated into the management information system to assist managers in completing their work. Various decision-aiding techniques dedicated to project portfolio selection problems are proposed in the literature [69, 70]. However, Yineng's leadership was inclined to rely on practical experience for project selection. This phenomenon is common in China [71, 72]. One reason is the Chinese culture of traditional officialism; officers prefer to have the final say [73]. Another reason is a lack of familiarity with scientific methods of optimization and decision making. After repeated discussions, the company's senior managers adopted a decision support system. The system shows the status of project portfolio, including project size, project schedule, resources, and the financial situation to decision-makers intuitively and simulates the status after adding new projects. The information helps to improve the reliability of an intuitive decision.

The work of Yineng's middle managers includes the development of a portfolio implementation plan, allocating resources to the portfolio, summarizing and analyzing project data, and communicating with stakeholders. Accurate and rapid data collection, processing, and delivery are necessary to accomplish these works efficiently. Project-related information is inputted by different stakeholders using the PPM information system. After classification and integration, the relevant information is sent to different portfolio managers. From these data, portfolio managers receive timely information concerning the project portfolio situation and can make rational and informed decisions. The decisions are communicated to the corresponding stakeholders through the system. Finally, execution feedback returns to the portfolio managers. The use of the PPM information system has greatly increased portfolio manager efficiency and effectiveness and enabled successful completion of tasks.

With the adjustment of Yineng's organizational structure, portfolio managers' work has improved. Communication and coordination with related parties (owners, suppliers, and logistics providers), which were previously undertaken by project managers, have been assumed by portfolio managers. The work content of the single-project manager is simplified so that project managers are now able to concentrate on project governance. The main responsibility for project managers is single-project management and the reporting of project performance through the management information system. We standardized the processes for each project activity and reflected them in the management information system. With the use of standardized processes, the complexity of the project manager's task is further reduced, while project control is increased $[33,74]$. Because the same type of project employs the same management standard, when a project encounters an emergency, other managers can provide personnel, equipment and technology support. The ability and willingness to collaborate across projects has increased.

\section{RESULTS AND DISCUSSION}

With the guidance of the PPM framework, Yineng has effectively solved the multi-projects management problem by establishing a proprietary PPM system. Additionally, with new role definitions, the company has adjusted its organizational structure and increased the number of middle managers to facilitate PPM integration. The traditional organizational structure has shifted from a pyramid shape to a bell shape (Fig. 6). Senior managers have been released from complex daily affairs and can focus on company strategy, and project managers are responsible for single-project management with the goal of improving performance. Some indicators may reflect the improvement of management efficiency at Yineng (Table 2). For reasons of confidentiality, we were not authorized to reveal all of the real data. The output value and net profit are represented by growth rate.

We received the commission from Yineng in October 2013 and finished the PPM transformation in April 2014. Table 2 shows that, with no obvious increase in the number of employees, Yineng contracted more projects, the output value increased by nearly $9 \%$, and average net profit did not decrease as it had in 2013. In 2013, the increase in projects and management burden caused most of the management indicators to deteriorate including the serious accident rate. In contrast, average net profit increased by $10.2 \%$ in 2014 . It is difficult to prove that the improvements are because of the PPM transformation directly. However, other indicators may partly explain the reason for the changes. After the PPM transformation, safety accident rates have reduced significantly, particularly the general accident rate, which decreased from 13.86 to 6.95 times per billion yuan. Compared with 2013, this alone reduced direct economic loss by more than three million yuan. Another important indicator, the rolled throughput yield of project-related work, increased from $86.4 \%$ to $94.1 \%$. This also greatly contributed to improvements in performance of projects by avoiding rework and reducing cost. In addition, the on-time projects rate and customer satisfaction also improved by varying degrees. This improved Yineng's reputation, competitiveness, and contributed to future development. 
Table 2. The management indicators of Yineng from 2012 to 2014.

\begin{tabular}{|c|c|c|c|c|c|c|c|c|c|}
\hline & \multirow{2}{*}{ Output Value } & \multirow{2}{*}{$\begin{array}{c}\text { Average Net } \\
\text { Profit }\end{array}$} & \multicolumn{3}{|c|}{ Accident Rate } & \multirow{2}{*}{$\begin{array}{c}\text { Rolled Throughput } \\
\text { Yield }\end{array}$} & \multirow{2}{*}{\begin{tabular}{|c|}
$\begin{array}{c}\text { On-time Projects } \\
\text { Rate }\end{array}$ \\
\end{tabular}} & \multirow{2}{*}{$\begin{array}{c}\text { Customer } \\
\text { Satisfaction }\end{array}$} & \multirow{2}{*}{$\begin{array}{l}\text { Number of } \\
\text { Employees }\end{array}$} \\
\hline & & & general & great & \begin{tabular}{|l|} 
serious \\
\end{tabular} & & & & \\
\hline 2012 & - & - & 16.01 & 0.43 & 0.00 & $88.6 \%$ & $77.4 \%$ & $87.2 \%$ & 789 \\
\hline 2013 & $3.3 \% \uparrow$ & $1.8 \%$ & 13.86 & 0.00 & 0.42 & $86.4 \%$ & $75.9 \%$ & $84.4 \%$ & 812 \\
\hline 2014 & $8.8 \% \uparrow$ & $10.2 \% \uparrow$ & 6.95 & 0.00 & 0.00 & $94.1 \%$ & $81.6 \%$ & $91.7 \%$ & 823 \\
\hline
\end{tabular}

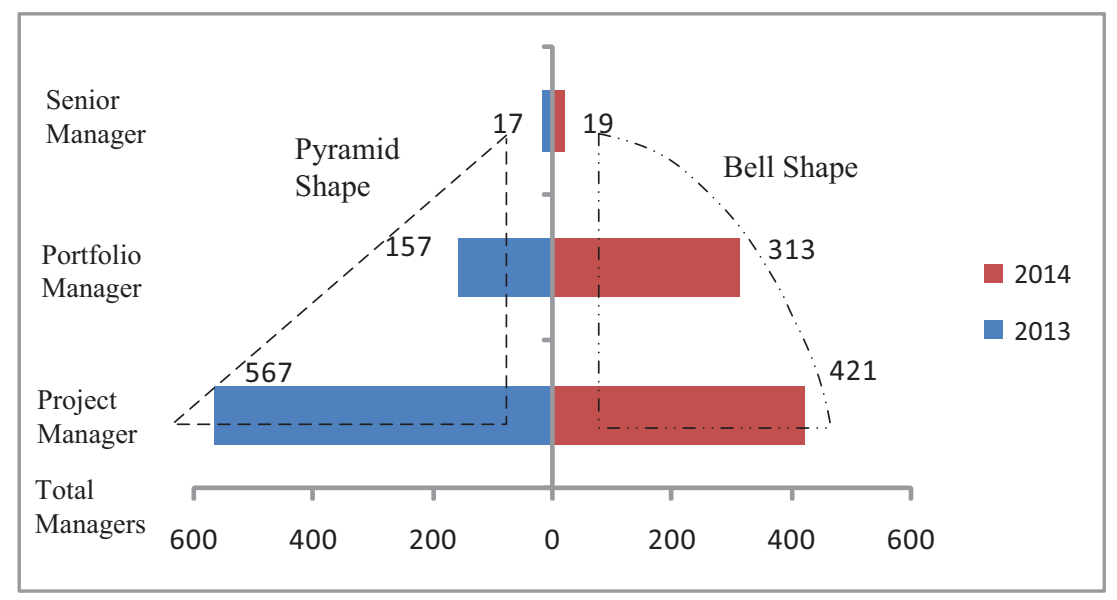

Fig. (6). The organizational structure of Yineng in 2013 and 2014.

These changes attributed to the improvements in management efficiency and control, which were derived from a series of PPM transformation measures. The standardized workflow based on the WBS provides clarification of the work content of project managers and improved single-project control. The complexity of the project portfolio is reduced, which is conducive to PPM effectiveness [75]. Moreover, the use of the management information system improved the timeliness and accuracy of information transfer. This is also beneficial for management efficiency [48, $76]$.

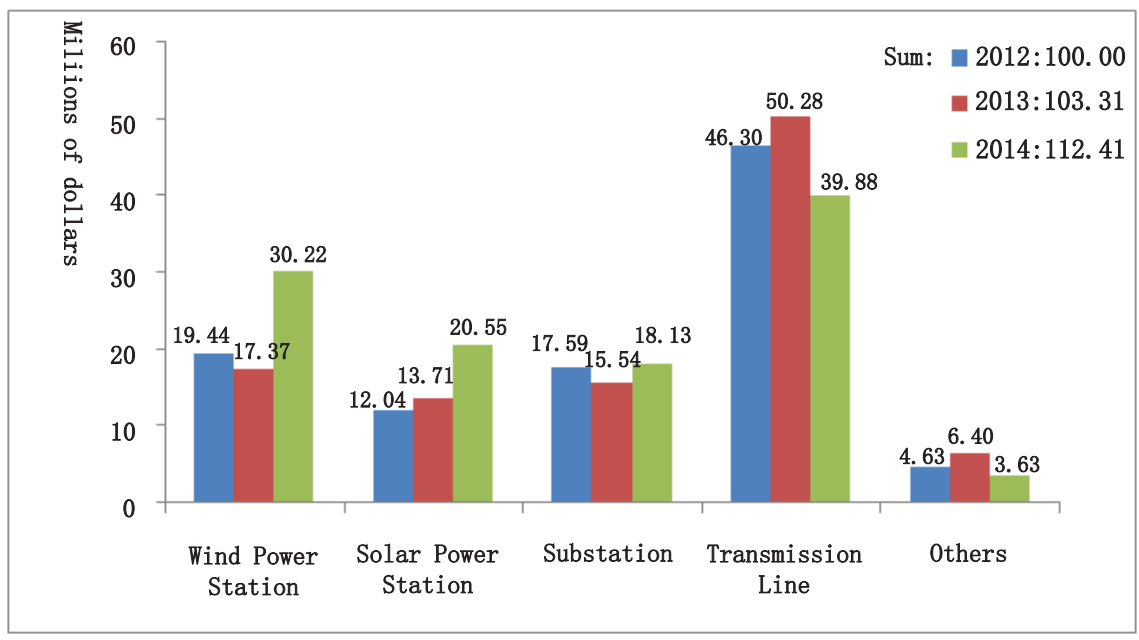

Fig. (7). The output values of different project types.

In addition to the increase in output, the constitution of the output value changed. We did not use the true output value for reasons of confidentiality. We used a certain coefficient to convert the total output value of 2012 to 100 million dollars. Then, we multiplied the other output values by this coefficient to obtain (Fig. 7). The columns with different colors represent the output values of Yineng in different years and project types. In Fig. (7), the output value of the wind power station and the solar power station increased significantly, whereas the value of the transmission line 
and others decreased. The distribution of output value could be seen as an indicator of strategy. Because the transmission line project is high-risk and the market competition is fierce, Yineng hoped to explore the new energy markets. In 2013, this strategy was not implemented effectively. But in 2014, it was achieved. These changes provide indirect arguments that the PPM transformation also has benefits for the design and implementation of strategy. In the subsequent visit, Yineng's senior managers admitted that, although they experienced difficulty accepting the decision support solutions initially, these support systems ultimately proved invaluable, particularly with respect to strategy.

\section{CONCLUSION}

This paper proposed a three-dimensional PPM framework for the construction industry as a special guide to enterprises that desire access to PPM and illustrated the framework's application and utility using a case study. The complex management issues were divided into simple tasks using three-dimensional segmentation. These tasks were then subdivided into three categories and assigned to three types of managers. Appropriate methods were recommended to assist managers in the optimal management of their work. The framework provides a clear guide for construction companies with no PPM experience for the development of a proprietary PPM system to improve business opportunity amid fierce market competition. Moreover, the PPM framework is an open source platform that can integrate other PPM approaches and provide specialized solutions for different companies in the industry. This facilitates the practical application of related research and adds to the limited PPM research concerning PPM practical application.

However, the study has limitations. First, this framework was developed for construction enterprises without established experience, but only one case study is selected to prove the feasibility of the PPM framework. Although we have analyzed its inner mechanism in detail, this is still not sufficient to justify this framework's effectiveness for all construction enterprises. Second, the framework in this paper must be applied in combination with other project management methods to maximize its function. However, the methods embedded in the system influence each other. Some of the methods can complement each other to motivate output results, whereas others may be restrictive and detrimental to implementation. Current research on the interplay of PPM methods is scarce. We attempted to fill this gap with the establishment of a management information system. Further exploration is required concerning the influence of PPM interplay in achieving project portfolio success.

This article provides one solution to the problem of PPM practical application, and not all multi-project management issues are applicable. We offer a new perspective to promote the application of PPM theory to practical outcomes.

\section{CONFLICT OF INTEREST}

The authors confirm that this article content has no conflict of interest.

\section{ACKNOWLEDGEMENTS}

Project supported by the National Nature Science Foundation of China (No.71271085) and the Fundamental Research Funds for the Central Universities (No. 2015XS40).

\section{REFERENCES}

[1] Y.G. Zhang, Y.H. Wang, and Y.Y. Zhao, "Construction project management actuality and countermeasures", Appl. Mech. Mater., vol. 501-504, pp. 2654-2658, 2014.

[http://dx.doi.org/10.4028/www.scientific.net/AMM.501-504.2654]

[2] C.S. Chen, Y.K. Tsui, R.J. Dzeng, and W.C. Wang, "Application of project-based change management in construction: a case study", J. Civil Eng. Manag., vol. 21, pp. 107-118, 2015. [http://dx.doi.org/10.3846/13923730.2013.802712]

[3] M. Young, and K. Conboy, "Contemporary project portfolio management: Reflections on the development of an Australian competency standard for project portfolio management", Int. J. Proj. Manag., vol. 31, pp. 1089-1100, 2013. [http://dx.doi.org/10.1016/j.ijproman.2013.03.005]

[4] B. Madic, V. Trujic, and I. Mihajlovic, "Project portfolio management implementation review", African J. Business Manag., vol. 5, pp. 240-248, 2011.

[5] M. Martinsuo, "Project portfolio management in practice and in context", Int. J. Proj. Manag., vol. 31, pp. $794-803,2013$. [http://dx.doi.org/10.1016/j.ijproman.2012.10.013]

[6] R. Bhattacharyya, P. Kumar, and S. Kar, "Fuzzy R\&D portfolio selection of interdependent projects", Comput. Math. Appl., vol. 62, pp. 3857-3870, 2011. 
[http://dx.doi.org/10.1016/j.camwa.2011.09.036]

[7] K. Khalili Damghani, S. Sadi Nezhad, F.H. Lotfi, and M. Tavana, "A hybrid fuzzy rule-based multi-criteria framework for sustainable project portfolio selection", Inf. Sci., vol. 220, pp. 442-462, 2013.

[http://dx.doi.org/10.1016/j.ins.2012.07.024]

[8] A.H. Ghapanchi, M. Tavana, M.H. Khakbaz, and G. Low, "A methodology for selecting portfolios of projects with interactions and under uncertainty", Int. J. Proj. Manag., vol. 30, pp. 791-803, 2012.

[http://dx.doi.org/10.1016/j.ijproman.2012.01.012]

[9] K. Girotra, C. Terwiesch, and K.T. Ulrich, "Valuing R\&D projects in a portfolio: Evidence from the pharmaceutical industry", Manage. Sci., vol. 53, pp. 1452-1466, 2007. [http://dx.doi.org/10.1287/mnsc.1070.0703]

[10] D. Quartel, M.W. Steen, and M.M. Lankhorst, "Application and project portfolio valuation using enterprise architecture and business requirements modelling", Enterprise Inf. Systs., vol. 6, pp. 189-213, 2012. [http://dx.doi.org/10.1080/17517575.2011.625571]

[11] H. Eilat, B. Golany, and A. Shtub, "Constructing and evaluating balanced portfolios of R\&D projects with interactions: A DEA based methodology", Eur. J. Oper. Res., vol. 172, pp. 1018-1039, 2006. [http://dx.doi.org/10.1016/j.ejor.2004.12.001]

[12] I. Bardhan, S. Bagchi, and R. Sougstad, "Prioritizing a portfolio of information technology investment projects", J. Manage. Inf. Syst., vol. 21, pp. 33-60, 2004.

[13] H. Kazemipoor, R. Tavakkoli Moghaddam, P. Shahnazari-Shahrezaei, and A. Azaron, "A differential evolution algorithm to solve multiskilled project portfolio scheduling problems", Int. J. Adv. Manuf. Technol., vol. 64, pp. 1099-1111, 2013. [http://dx.doi.org/10.1007/s00170-012-4045-z]

[14] J. Alberto Arauzo, J. Pajares, and A. Lopez Paredes, "Simulating the dynamic scheduling of project portfolios", Simul. Model. Pract. Theory, vol. 18 , pp. 1428-1441, 2010.

[http://dx.doi.org/10.1016/j.simpat.2010.04.008]

[15] Z. Laslo, "Project portfolio management: An integrated method for resource planning and scheduling to minimize planning/schedulingdependent expenses", Int. J. Proj. Manag., vol. 28, pp. 609-618, 2010. [http://dx.doi.org/10.1016/j.ijproman.2009.10.001]

[16] The Standard for Portfolio Management., $2^{\text {nd }}$ ed. Project Management Institute: Newtown Square, PA, 2008.

[17] A Guide to the Project Management Body of Knowledge (PMBOK Guide)., $4^{\text {th }}$ ed. Project Management Institute, Inc.: Newtown Square, PA., 2009.

[18] C. Benko, and F.W. McFarlan, Connecting the Dots: Aligning Projects with Objectives in Unpredictable Times, Harvard Business Press: Bostan, New York, 2003.

[19] R.G. Cooper, S.J. Edgett, and E.J. Kleinschmidt, Portfolio Management for New Products, Basic Books: New York, 2001.

[20] W. Heising, "The integration of ideation and project portfolio management - A key factor for sustainable success", Int. J. Proj. Manag., vol. 30, pp. 582-595, 2012.

[http://dx.doi.org/10.1016/j.ijproman.2012.01.014]

[21] D.I. Jung, C. Chow, and A. Wu, "The role of transformational leadership in enhancing organizational innovation: Hypotheses and some preliminary findings", Leadersh. Q., vol. 14, pp. 525-544, 2003. [http://dx.doi.org/10.1016/S1048-9843(03)00050-X]

[22] D.D. Jung, A. Wu, and C.W. Chow, "Towards understanding the direct and indirect effects of CEOs' transformational leadership on firm innovation", Leadersh. Q., vol. 19, pp. 582-594, 2008. [http://dx.doi.org/10.1016/j.leaqua.2008.07.007]

[23] E. Gutiérrez, and M. Magnusson, "Dealing with legitimacy: A key challenge for project portfolio management decision makers", Int. J. Proj. Manag., vol. 32, pp. 30-39, 2014.

[http://dx.doi.org/10.1016/j.ijproman.2013.01.002]

[24] J. Kissi, A. Dainty, and M. Tuuli, "Examining the role of transformational leadership of portfolio managers in project performance", Int. J. Proj. Manag., vol. 31, pp. 485-497, 2013. [http://dx.doi.org/10.1016/j.ijproman.2012.09.004]

[25] J. Kissi, R. Payne, S. Luke, A. Dainty, and A. Liu, "A study of the role of middle management in developing innovation climate in construction support services organisations", Proc. $25^{\text {th }}$ Annual ARCOM Conf., 2009, pp. 75-84.

[26] C. Beringer, D. Jonas, and A. Kock, "Behavior of internal stakeholders in project portfolio management and its impact on success", Int. J. Proj. Manag., vol. 31, pp. 830-846, 2013. [http://dx.doi.org/10.1016/j.ijproman.2012.11.006]

[27] C. Beringer, D. Jonas, and H.G. Gemuenden, "Establishing project portfolio management: an exploratory analysis of the influence of internal stakeholders' interactions", Proj. Manage. J., vol. 43, pp. 16-32, 2012.

[http://dx.doi.org/10.1002/pmj.21307] 
[28] B.N. Unger, H.G. Gemünden, and M. Aubry, "The three roles of a project portfolio management office: Their impact on portfolio management execution and success", Int. J. Proj. Manag., vol. 30, pp. 608-620, 2012. [http://dx.doi.org/10.1016/j.ijproman.2012.01.015]

[29] J.Y. Liu, V.J. Chen, C.L. Chan, and T. Lie, "The impact of software process standardization on software flexibility and project management performance: Control theory perspective", Inf. Softw. Technol., vol. 50, pp. 889-896, 2008. [http://dx.doi.org/10.1016/j.infsof.2008.01.002]

[30] D. Milosevic, and P. Patanakul, "Standardized project management may increase development projects success", Int. J. Proj. Manag., vol. 23, pp. 181-192, 2005.

[http://dx.doi.org/10.1016/j.ijproman.2004.11.002]

[31] D. Milosevic, and L. Inman, "Impact of project management standardization on project effectiveness", Eng. Manag. J., vol. 13, pp. 9-16, 2001 . [http://dx.doi.org/10.1080/10429247.2001.11415133]

[32] E.J. Kleinschmidt, U. De Brentani, and S. Salomo, "Performance of global new product development programs: a resource based view", J. Prod. Innov. Manag., vol. 24, pp. 419-441, 2007. [http://dx.doi.org/10.1111/j.1540-5885.2007.00261.x]

[33] J.M. Bonner, R.W. Ruekert, and O.C. Walker, "Upper management control of new product development projects and project performance", J. Prod. Innov. Manag., vol. 19, pp. 233-245, 2002. [http://dx.doi.org/10.1111/1540-5885.1930233]

[34] M. Lerch, and P. Spieth, "Innovation project portfolio management: A qualitative analysis", IEEE Trans. Eng. Manag., vol. 60, pp. 18-29, 2013. [http://dx.doi.org/10.1109/TEM.2012.2201723]

[35] D. Jonas, A. Kock, and H.G. Gemuenden, "Predicting project portfolio success by measuring management quality-A longitudinal study", IEEE Trans. Eng. Manag., vol. 60, pp. 215-226, 2013. [http://dx.doi.org/10.1109/TEM.2012.2200041]

[36] C.P. Killen, and R.A. Hunt, "Robust project portfolio management: capability evolution and maturity", Int. J. Manag. Projects Business, vol. 6, pp. 131-151, 2013. [http://dx.doi.org/10.1108/17538371311291062]

[37] Y. Petro, and P. Gardiner, "An investigation of the influence of organizational design on project portfolio success, effectiveness and business efficiency for project-based organizations", Int. J. Proj. Manag., vol. 33, pp. 1717-1729, 2015. [http://dx.doi.org/10.1016/j.ijproman.2015.08.004]

[38] A. Mosavi, "Exploring the roles of portfolio steering committees in project portfolio governance", Int. J. Proj. Manag., vol. 32, pp. 388-399, 2014

[http://dx.doi.org/10.1016/j.ijproman.2013.07.004]

[39] A. Zika Viktorsson, P. Sundström, and M. Engwall, "Project overload: an exploratory study of work and management in multi-project settings", Int. J. Proj. Manag., vol. 24, pp. 385-394, 2006. [http://dx.doi.org/10.1016/j.ijproman.2006.02.010]

[40] A. Leonard, and A. Swanepoel, "Project portfolio management implementation pitfalls", South African J. Business Manag., vol. 41, pp. 13-22, 2010

[41] Y. Petit, "Project portfolios in dynamic environments: Organizing for uncertainty", Int. J. Proj. Manag., vol. 30, pp. 539-553, 2012. [http://dx.doi.org/10.1016/j.ijproman.2011.11.007]

[42] J. Davidson Frame, "Mastering project portfolio management: a systems approach to achieving strategic objectives", Proj. Manage. J., vol. 43, pp. 112-112, 2012. [http://dx.doi.org/10.1002/pmj.21309]

[43] W.J. Gutjahr, and K.A. Froeschl, "Project portfolio selection under uncertainty with outsourcing opportunities", Flexible Ser. Manufact. J., vol. 25 , pp. 255-281, 2013. [http://dx.doi.org/10.1007/s10696-011-9107-2]

[44] J. Liesio, and A. Salo, "Scenario-based portfolio selection of investment projects with incomplete probability and utility information", Eur. J. Oper. Res., vol. 217, pp. 162-172, 2012.

[http://dx.doi.org/10.1016/j.ejor.2011.08.025]

[45] A.F. Carazo, T. Gomez, J. Molina, A.G. Hernandez Diaz, F.M. Guerrero, and R. Caballero, "Solving a comprehensive model for multiobjective project portfolio selection", Comput. Oper. Res., vol. 37, pp. 630-639, 2010. [http://dx.doi.org/10.1016/j.cor.2009.06.012]

[46] X. Kefan, "A risky decision-making model for combination of technological innovation projects", J. Wuhan Inst. Technol., vol. 03, pp. 91-98, 1994.

[47] A. Jerbrant, and T.K. Gustavsson, "Managing project portfolios: balancing flexibility and structure by improvising", Int. J. Manag. Projects Business, vol. 6, pp. 152-172, 2013. [http://dx.doi.org/10.1108/17538371311291071] 
[48] M. Braglia, and M. Frosolini, "An integrated approach to implement project management information systems within the extended enterprise", Int. J. Proj. Manag., vol. 32, pp. 18-29, 2014. [http://dx.doi.org/10.1016/j.ijproman.2012.12.003]

[49] S. Riddell, and W.A. Wallace, "The use of fuzzy logic and expert judgment in the R\&D project portfolio selection process", Int. J. Technol. Manag., vol. 53, pp. 238-256, 2011. [http://dx.doi.org/10.1504/IJTM.2011.038592]

[50] B.V. Smith, and M.G. Ierapepritou, "Modeling and optimization of product design and portfolio management interface", Comput. Chem. Eng., vol. 35 , pp. 2579-2589, 2011.

[http://dx.doi.org/10.1016/j.compchemeng.2011.06.009]

[51] F. Bouraad, "IT project portfolio governance: the emerging operation manager", Proj. Manag. J., vol. 41, pp. 74-86, 2010. [http://dx.doi.org/10.1002/pmj.20083]

[52] X. Zhao, B.G. Hwang, and W. Phng, "Construction project risk management in Singapore: resources, effectiveness, impact, and understanding", KSCE J. Civil Eng., vol. 18, pp. 27-36, 2014. [http://dx.doi.org/10.1007/s12205-014-0045-x]

[53] R. Muller, M. Martinsuo, and T. Blomquist, "Project portfolio control and portfolio management performance in different contexts", Proj. Manag. J., vol. 39, pp. 28-42, 2008. [http://dx.doi.org/10.1002/pmj.20053]

[54] X. Ferrada, and A. Serpell, "Selection of construction methods for construction projects: A knowledge problem", J. Constr. Eng. Manag., vol. 140, p. B4014002, 2014.

[http://dx.doi.org/10.1061/(ASCE)CO.1943-7862.0000715]

[55] P. Bowen, P. Edwards, H. Lingard, and K. Cattell, "Occupational stress and job demand, control and support factors among construction project consultants", Int. J. Proj. Manag., vol. 32, pp. 1273-1284, 2014. [http://dx.doi.org/10.1016/j.ijproman.2014.01.008]

[56] N. Guo, and S.W. Yu, "The necessity of project portfolio management in the construction industry of China mainland", App. Mech. Mate., vol. 357 , pp. $2238-2241,2013$.

[http://dx.doi.org/10.4028/www.scientific.net/AMM.357-360.2238]

[57] T. Blomquist, and R. Müller, "Practices, roles, and responsibilities of middle managers in program and portfolio management", Proj. Manag. J., vol. 37, pp. 52-66, 2006.

[58] E. Fernandez, E. Lopez, G. Mazcorro, R. Olmedo, and C.A. Coello, "Application of the non-outranked sorting genetic algorithm to public project portfolio selection", Inf. Sci., vol. 228, pp. 131-149, 2013. [http://dx.doi.org/10.1016/j.ins.2012.11.018]

[59] M.M. Fouladgar, A. Yazdani Chamzini, E.K. Zavadskas, S.H. Yakhchali, and M.H. Ghasempourabadi, "Project portfolio selection using fuzzy AHP and VIKOR techniques", Transform. Bus. Econ., vol. 11, pp. 213-231, 2012.

[60] A. Smith Perera, M. Garcia Melon, R. Poveda Bautista, and J.P. Pastor Ferrando, "A project strategic index proposal for portfolio selection in electrical company based on the analytic network process", Renew. Sustain. Energy Rev., vol. 14, pp. 1569-1579, 2010. [http://dx.doi.org/10.1016/j.rser.2010.01.022]

[61] C.C. Wei, and H.W. Chang, "A new approach for selecting portfolio of new product development projects", Expert Syst. Appl., vol. 38, pp. 429-434, 2011. [http://dx.doi.org/10.1016/j.eswa.2010.06.081]

[62] H.R. Abbasianjahromi, and H. Rajaie, "Application of fuzzy CBR and MODM approaches in the project portfolio selection in construction companies", Iranian J. Science Technol. Trans. Civil Eng., vol. 37, pp. 143-155, 2013.

[63] W.G. Zhang, Q. Mei, Q. Lu, and W.L. Xiao, "Evaluating methods of investment project and optimizing models of portfolio selection in fuzzy uncertainty", Comput. Ind. Eng., vol. 61, pp. 721-728, 2011. [http://dx.doi.org/10.1016/j.cie.2011.05.003]

[64] G. Hu, L. Wang, S. Fetch, and B. Bidanda, "A multi-objective model for project portfolio selection to implement lean and Six Sigma concepts", Int. J. Prod. Res., vol. 46, pp. 6611-6625, 2008. [http://dx.doi.org/10.1080/00207540802230363]

[65] W.J. Gutjahr, S. Katzensteiner, P. Reiter, C. Stummer, and M. Denk, "Multi-objective decision analysis for competence-oriented project portfolio selection", Eur. J. Oper. Res., vol. 205, pp. 670-679, 2010. [http://dx.doi.org/10.1016/j.ejor.2010.01.041]

[66] K.H. Rose, "Governance frameworks for public project development and estimation", Proj. Manag. J., vol. 39, pp. S27-S42, 2010.

[67] O.J. Ameh, and K. Odusami, "The leadership profile of Nigerian construction project managers", Scientia Iranica. Transaction A. Civ. Eng., vol. 21, p. 1241, 2014 .

[68] Y. Wu, and R. Xu, "Current status, future potentials and challenges of renewable energy development in Gansu province (Northwest China)", Renew. Sustain. Energy Rev., vol. 18, pp. 73-86, 2013. [http://dx.doi.org/10.1016/j.rser.2012.09.038] 
[69] A.T. Almeida, and M.D. Duarte, "A multi-criteria decision model for selecting project portfolio with consideration being given to a new concept for synergies", Pesquisa Operacional, vol. 31, pp. 301-318, 2011. [http://dx.doi.org/10.1590/S0101-74382011000200006]

[70] A.F. Carazo, I. Contreras, T. Gomez, and F. Perez, "A project portfolio selection problem in a group decision-making context", J. Industrial Manag. Optimi., vol. 8, pp. 243-261, 2012. [http://dx.doi.org/10.3934/jimo.2012.8.243]

[71] X. Qi, C. Yi, and J. Li, "The problems in PPP project decision process in china comparing with Singapore", In: L. Tian, H. Hou, and J. Li, Eds., Architecture, Building Materials And Engineering Management, Pts 1-4, vol. 357. 2013, pp. 2519-2523. [http://dx.doi.org/10.4028/www.scientific.net/AMM.357-360.2519]

[72] X. Pan, and X. Ma, "Research on local governments, strategies of loss-making regional airports in China", Proc. 2013 Int. Conf. Public Admin., Chengdu: China, 2013.

[73] T.H. Li, S.T. Ng, and M. Skitmore, "Public participation in infrastructure and construction projects in China: From an EIA-based to a wholecycle process", Habitat Int., vol. 36, pp. 47-56, 2012. [http://dx.doi.org/10.1016/j.habitatint.2011.05.006]

[74] J. Teller, B.N. Unger, A. Kock, and H.G. Gemünden, "Formalization of project portfolio management: The moderating role of project portfolio complexity", Int. J. Proj. Manag., vol. 30, pp. 596-607, 2012. [http://dx.doi.org/10.1016/j.ijproman.2012.01.020]

[75] R. Zeynalzadeh, and A. Ghajari, "A framework for project portfolio selection with risk reduction approach", African J. Bus. Manag., vol. 5, pp. 10474-10482, 2011.

[76] S. Kubota, and I. Mikami, "Data model-centered four-dimensional information management system for road maintenance", J. Comput. Civ. Eng., vol. 27, pp. 497-510, 2013. [http://dx.doi.org/10.1061/(ASCE)CP.1943-5487.0000176]

(C) Wu et al.; Licensee Bentham Open.

This is an open access article licensed under the terms of the Creative Commons Attribution-Non-Commercial 4.0 International Public License (CC BY-NC 4.0) (https://creativecommons.org/licenses/by-nc/4.0/legalcode), which permits unrestricted, non-commercial use, distribution and reproduction in any medium, provided the work is properly cited. 